\title{
Evaluating the Impact of School Decentralization on Education Quality
}

\author{
Sebastián Galiani \\ UdeSA \\ and \\ Ernesto Schargrodsky* \\ UTDT
}

September 19, 2001

\begin{abstract}
An important piece of the major fiscal and structural reforms undertaken in Argentina in the early 1990's was the decentralization of education services from the federal government to the provincial governments. The theoretical literature does not find absolute superiority of centralization or decentralization in the provision of public services. We evaluate empirically the effect of the decentralization of secondary schools in Argentina on education quality. Our results suggest that, on average, decentralization improved the performance of public school students in test scores. We also explore whether the effect of decentralization depends on province characteristics. We find that the effect is positive when schools are transferred to fiscally ordered provinces, but negative when provinces run significant fiscal deficits.
\end{abstract}

JEL: H40, H52, H70, I20

Keywords: Decentralization, evaluation, education quality.

\footnotetext{
* Sebastián Galiani, Universidad de San Andrés, Vito Dumas 284, (B1644BID) Victoria, Provincia de Buenos Aires, Argentina, Tel: (54-11) 4746-2608, sgaliani@udesa.edu.ar. Ernesto Schargrodsky, Universidad Torcuato Di Tella, Miñones 2177, (C1428ATG) Buenos Aires, Argentina, Tel: (54-11) 4784-0080, eschargr@utdt.edu. This paper was done while Sebastián Galiani was Assistant Professor at UTDT. We give thanks to Fernando Alvarez, Paul Gertler, and to seminar participants at Universidad Torcuato Di Tella for useful comments. Luciana Esquerro provided good research assistance.
} 


\section{Introduction}

Decentralization is a major component of current institutional innovation throughout the world. In Latin America, most countries implemented decentralization policies in the recent past after a long tradition of centralized government (Burki, Perry, and Dillinger, 1999). ${ }^{1}$ Argentina has not been the exemption. An important piece of the structural reforms undertaken in Argentina in the early 1990's was the decentralization of education services from the federal government to the provincial governments.

The main argument in support of decentralization policies is to bring decisions closer to the people. Information asymmetries, agency costs and problems of collective decision can be alleviated through decentralization. However, decentralization can also worsen the provision of public goods in the presence of positive spillovers, lack of technical capabilities by local governments, or capture of low-level administrations by local elites. Thus, the theoretical literature obtains trade-offs without universal superiority of centralization or decentralization in the provision of public services. The problem needs to be analyzed empirically.

In this paper, we evaluate the effect of secondary school decentralization in Argentina on education quality. Between 1992 and 1994, the national government transferred to the provincial governments all its dependent secondary schools. ${ }^{2}$ This

\footnotetext{
${ }^{1}$ Recent studies analyzing decentralization processes in Latin America include Lopez Murphy (1995), Tendler (1997), Bird and Vaillancourt (1998), Fukasaku and Hausmann (1998), Savedoff (1998), and Willis et al (1999). On Argentina, see Porto and Gasparini (1998), Grindle (2000), Tomassi, Saiegh, and Sanguinetti (2000), inter alia.

${ }^{2}$ The decentralization of education services in Argentina was not an isolated program but a piece of an extensive program of fiscal and structural reforms accomplished during the early 1990's. Some prominent examples of the reforms implemented the Argentine government are a massive privatization program, a broad trade liberalization process, a reform and privatization of the national pension system, the emancipation of the Central Bank, and the decentralization of both education and health services to provincial governments.
} 
political experiment generates an exogenous variation in the jurisdiction of administration of secondary schools across time and space. We exploit this instrument to identify the causal effect of school decentralization on education quality, measured by the outcome of a standardized test of Language and Mathematics administered to students in their final year of secondary school.

An advantageous feature of our study is that we not only control the performance of students on test scores by the evolution of observable variables but, by contrasting public and private school test outcomes, we are also able to control the performance of students on test outcomes by the effect of unobservable factors that could differentially affect the evolution of student performance in each province. Thus, our estimator of the effect of school decentralization on test outcomes is the conditional difference in difference of the difference of public and private test outcomes. Our results suggest that, on average, decentralization improved the performance of students in test scores.

As theoretical results suggest, we also interact the decentralization policies with measures of province characteristics: fiscal performance, political alternation, and province size (surface, population and density). We find that the effect of school decentralization on test outcomes is heterogeneous with respect to provincial fiscal performances. The effect of decentralization on test scores is positive when schools are transferred to fiscally ordered provinces, but negative when provinces run significant fiscal deficits. If fiscal performance proxies for the technical capabilities of local administrations, our results suggest that decentralization is deleterious when services are transferred to low-quality local governments. We also find that the effect of school 
decentralization on test outcomes is not heterogeneous with respect to the other characteristics interacted.

Two related papers analyze the effect of decentralization on education in Argentina. Their approaches are quite different from ours. Eskeland and Filmer (2000) find that school decision autonomy and parental participation (proxied by survey measures) raise test scores. However, their cross-section study does not rule out the possibility that autonomy and participation are endogenously determined. Habibi et al (2001) find a positive effect of fiscal decentralization (measured by revenue-sharing ratios between the provinces and the federal government) on secondary school enrollment at the province level. Without controlling by trend or year effects, their results may be capturing a spurious correlation. None of these papers analyze an explicit policy intervention of school decentralization.

The organization of the paper is as follows. Section 2 discusses potential trade-offs in school decentralization. Section 3 explains the process of decentralization of secondary schools in Argentina. Section 4 describes our empirical exercise and Section 5 presents our results. In the last section, we summarize our conclusions.

\section{Decentralization Trade-Offs}

The theoretical literature obtains trade-offs without absolute dominance of centralization or decentralization in the provision of public services. In Oates (1972), central governments produce a common level of public goods for all localities, while local governments can tailor public goods output to local tastes. He finds that local 
governments are preferable when the better match between local government outputs and local preferences is not outweighed by spillovers or economies of scale in central government provision. Lockwood (1998) and Besley and Coate (2000) allow for heterogeneous local provision but central policy making in which elected representatives bargain over public goods provision. With heterogeneous provision, the case for decentralization has to be driven by political economy considerations, i.e. drawbacks in the political and legislative processes of centralized systems that may induce inequity, uncertainty, or excessive public spending.

Bardhan and Mookherjee (1998) trade off limited central government ability to monitor the bureaucrats against capture by local elites under decentralization. If the capture of political process by interest groups is easier at the local level (by interest groups that are locally big but nationally small), then decentralization will tend to favor those local groups disproportionately. In Tommasi and Weinschelbaum (1999), the advantages of centralized decision making (internalization of externalities) are compared to those of decentralized decision making (increased control of agents by the citizens through lower information asymmetries, less free-riding and easier coordination). In addition, decentralization may have the advantage of encouraging competition if citizens "vote with their feet" (Tiebout, 1956).

Thus, the main argument in favor of decentralization is to bring decisions closer to the people. The problems of information asymmetries over heterogeneous preferences, and the problems of collective decision and accountability in controlling political agents can be alleviated with decentralization. In addition, decentralization may encourage competition. However, decentralization may worsen the provision of public goods if 
there are positive externalities, if low-level governments lack technical capabilities, or if local administrations are captured by local elites that face reduced political competition within the region.

Most of these advantages and disadvantages may be relevant in the provision of educational services in Argentina. Lack of expertise of local management, and capture by corrupt local elites (Bardhan and Mookherjee, 1998; Rose-Ackerman, 1999) are potentially important in our context. The presence of positive externalities in education has been pointed out by Adam Smith and Alfred Marshall. Becker (1964) and Lucas (1988) argue that education social returns exceed private returns, although Heckman and Klenow (1997) question these externalities. In our context, however, it is arguable whether these externalities are exhausted at the province level, or whether they spill to the whole country.

The advantages of having "policy closer to the people" may also be relevant in our context. The explicit reasons for the school transfer in Argentina were to increase efficiency and efficacy through proximity to demand and unification of management and control at the province level (Llach et al, 1999). Faguet (2001)'s results on Bolivian decentralization suggest that local government have better knowledge of idiosyncratic preferences. As mentioned, Eskeland and Filmer (2001) find a positive effect of parental participation on school performance. Paes de Barros and Mendonca (1998) find no effect on test performance of school financial autonomy and school boards in Brazil, but positive effects of decentralized director appointment. Decentralization seem to lower users' costs of putting pressure on the schools to improve their services through voice and 
participation in El Salvador and Nicaragua (Jimenez and Sawada, 1999; King and Ozler, 2000).

Regarding competition for students, previous empirical work shows that competition can improve schools (Hoxby, 2000). However, as it will be described in the next section, decentralization of secondary schools in Argentina from the federal to provincial governments implied less, rather than more, competition in the provision of public school services. In most Argentine provinces, national and provincial schools "competed" before decentralization in the same cities, but uniform provincial provision remained after decentralization.

\section{School Decentralization in Argentina}

The traditional organization of the school system in Argentina had three stages: PreSchool, Primary School (mandatory, 7 years), and Secondary School. Throughout the country, school services were provided by public (national, provincial, and municipal) and private schools. There were three types of secondary schools: general ("bachiller" -5 years-), commercial (“comercial" -5 years-) and technical ("tecnico" -6 years-). By Law 24.049 (December 5, 1991), the Argentine Congress established the transfer of federal secondary schools from the national government to the provincial governments. ${ }^{3}$

Most Argentine provinces already administered a significant proportion of secondary schools. For historical reasons, this proportion was very heterogeneous across provinces (Dussel, 1995). Before the decentralization process, students in federal secondary schools 
represented $61 \%$ of total public students, fluctuating from $8 \%$ in Rio Negro to $100 \%$ in Tierra del Fuego. ${ }^{4}$ By 1994, less than $3 \%$ of public secondary school students studied in federal schools. ${ }^{5,6}$

The Decentralization Law stated that school transfers would be scheduled through the signature of bilateral agreements between the federal government and each province. These agreements introduced variability across provinces in transfer dates. According to the bilateral agreements, secondary school decentralization took place between February 1992 and January 1994. The transfer dates were unrelated to education quality. The heterogeneity originated in political conflicts between the Nation and the provincial governments (Rothen, 1999). ${ }^{7}$

This significant variation in the degree and timing of the decentralization process across provinces allows us to identify its effects on education quality controlling for fixed and year effects. Table 1 shows the decentralization month, and the initial and final shares of national school students in total public school students by province.

\footnotetext{
${ }^{3}$ Decentralization of primary and pre-schools started in 1961 and ended in 1978 (Law-Decree 21.809 and Complementary Law 21.810). For a historical description of the Argentine educational system, see Llach et al (1999), Annex IV.1.

${ }^{4}$ In Rio Negro, general secondary schools had been transferred to the province in 1971 (Dussel, 1995). Tierra del Fuego is the youngest Argentine province. It was transformed from a national territory into a province in September 1992.

5 A handful of secondary schools remained under federal administration (a few specifically named technical schools, and schools belonging to national universities, security forces or other autarchic units).

${ }^{6}$ The share of municipal secondary school students grew with decentralization from $0.2 \%$ to $7 \%$. However, $98 \%$ of this $7 \%$ correspond to the City of Buenos Aires, the only district in which municipal secondary schools are relevant. Although it is not a province, but a federal district, we treat the City of Buenos Aires as a province in this study. Until the Constitutional Reform of 1994, the city authorities were directly elected by the President. After the reform, they are appointed through general elections.

7 The Spearman rank coefficients do not reject independence between the order of the transfer date, and the test score rankings (both for the 1993 province scores and for the 1994 public school scores).
} 
Decentralization in Argentina transferred secondary schools from the federal government to the provincial governments. The transfer included the budget and the personnel increasing province expenditures and revenues in the same amount. The administration of subsidies and the regulation of private schools were also transferred. The transfer affected the most important school decisions, as these are not taken at the school level. OECD (1998) shows that most education decisions in Argentina are now taken at intermediate (i.e., provincial) levels. The determination of expenditures, the allocation of personnel and non-personnel budget, the appointment and dismissal of directors, teachers and staff, the wage decisions, the definition of the calendar year, and the opening or closure of schools and sections are decisions transferred with the schools from the nation to the province levels. Schools only choose textbooks, teaching methods, evaluation methods, and (partially) contents, but in consultation with the provincial authority (see Table 4.2, Burki et al, 1999; and Table 9, Llach et al, 1999).

The national government transferred the schools, but it is in charge of performance measurement through the administration of standardized tests. Since 1993, the National Education Ministry annually tests fifth-year secondary school students in Language and Mathematics through the National System of Education Quality Evaluation (SINEC). ${ }^{8}$ We use these test scores to measure school quality. The 1993 test was experimental and the results are not available separately for public and private schools. For 1994 through 1996, a sample of students was tested in each province. ${ }^{9}$ After 1997, every fifth-year student has to answer the test. The Education Ministry does not provide the test results at

\footnotetext{
${ }^{8}$ Natural and Social Sciences were also evaluated for 1994 and 1997. Results are not internationally comparable as Argentina does not participate in TIMMS (Third International Mathematics and Science Survey). Seventh-grade primary students are also regularly tested.

${ }^{9}$ The sample design is described in Llach et al. (1999).
} 
the school level prior to 1997 . Thus, our measure of education quality is only available at the province level, the unit of analysis for our study. ${ }^{10}$

The results are available for three groups: general and commercial public schools, general and commercial private schools, and technical schools. As the technical school results are not available for public and private schools separately, we only consider nontechnical schools. We averaged the Language and Math grades for both public and private schools. ${ }^{11}$ By 1998, all high school students had passed the five years of their secondary schooling under provincial administration. For this reason, we do not consider test results after that date. Thus, we should have five observations (1994 through 1998) for 24 provinces, although for the province of Santa Cruz the results are not available for private schools for 1994, and for public and private schools for 1995.

Other performance measures are also regularly used in school system evaluations. Typical measures are the gross schooling rate (ratio of number of students to population size of that age), the net schooling rate (ratio of number of students in appropriate grade for their age to population size of that age), the repetition rate (ratio of number of repeating students to total students), ${ }^{12}$ the on-time graduation rate (ratio of number of ontime graduating students to number of initial class students), and the over-age rate (ratio of number of students of appropriate age to number of students). However, these variables tend to measure coverage rather than quality. For example, school requirements may loosen, inducing lower repetition and over-age rates, and higher schooling and ontime graduation rates, together with a deterioration in quality. Moreover, these variables

\footnotetext{
${ }^{10}$ Habibi et al (2001) also consider provinces as the appropriate unit of analysis for their study of fiscal decentralization in Argentina.

${ }^{11}$ The average test scores in our sample (percentage of correct answers) are 55\% for public schools, and $64 \%$ for private schools.
} 
are easily affected by administrative school decisions (that could be correlated with decentralization), ${ }^{13}$ and uniform measurement is unwarranted. Moreover, there exist significant data restrictions in Argentina. Most of these alternative measures are not available, or are only defined at the province level, without possible comparison between public and private schools. We prefer to use nationally administered test scores, a uniform, popular, monotonous, and good quality measure of school performance, although we recognize that standardized test scores do not capture all the dimensions of students' achievements.

After school decentralization, another important law affected the Argentine education system. Among other reforms, the Education Federal Law (Law 24.195, April 14,1993 ), replaced the seven years of primary school and five (or six) years of secondary school with a nine-year uniform cycle (EGB, Educacion General Basica) and a threeyear specialized cycle (Polimodal). Preschool and EGB were made mandatory. The Law applies to both public and private schools in every province. The Education Federal Law has been being gradually implemented across provinces and several issues are still pending (Ministerio de Educacion, 2001). As the implementation of the Law differs in time and degree across provinces, and as this policy applies to both public and private schools, the effect of this additional reform on students' performance will be controlled by our difference in difference of the public-private difference approach.

\footnotetext{
${ }^{12}$ In Argentina, students that do not make the grade have to "repeat" the course the next year.

${ }^{13}$ Schools could also intend to affect test scores, for example, through emphasis on test practice, although in Argentina there are no rewards or punishments conditional on test outcomes.
} 


\section{Our empirical exercise}

Our objective is to identify the effect of secondary school decentralization on education quality measured by the outcome of a standardized test. As it is generally recognized, however, the identification of the effect of school decentralization on education quality requires attention to the fact that the variation in the jurisdiction of administration of schools may not be orthogonal to unobservable factors that jointly affect the outcomes studied. To address this endogenity problem, we exploit an unusual policy experiment: the Argentine secondary school decentralization process of the 1990's. This political experiment generates an exogenous variation in the jurisdiction of administration of secondary schools across time and space that provides an instrument to identify the causal effect of school decentralization on test outcomes.

Secondary school decentralization was one piece of the major structural reforms undertaken in Argentina during that period. As explained in the previous section, all the provinces were treated (i.e., all national schools were decentralized) although at different periods and with different intensities. For political reasons, decentralization took place gradually between 1992 and 1994. For historical reasons, most provinces already had a significant number of secondary schools under their administration and the proportion of students in the schools administered by provincial governments before the decentralization process varied significantly. The Argentine decentralization experiment induced an exogenous variation in the administration of secondary schools across units and time. Our identification strategy exploits the fact that exposure to school decentralization of a secondary school final-year student varied both by province and student cohort. 
Suppose one is interested in estimating the influence of a policy instrument on an outcome for a group (e.g., the effect of school decentralization on test outcomes). ${ }^{14}$ The group consists of units $i=1 \ldots N$ observed over a sample horizon $t=1 \ldots T$. Suppose further that the policy instrument changes in a particular period $t$ for a segment of the group (or, as in our case, that it changes for all the segments but at different points in time). Let $\mathrm{dI}_{\mathrm{it}}$ be a zero-one indicator that equals unity if the policy change was operative for individual $\mathrm{i}$ in period t. Members of the group who experience the policy change react according to a parameter $\alpha_{0}$. The standard statistical model to estimate $\alpha_{0}$ is the following two-way fixed effect error component model:

$$
\mathrm{y}_{\mathrm{it}}=\dot{a}_{0} \mathrm{dI}_{\mathrm{it}}+\ddot{\mathrm{e}}_{\mathrm{t}}+\grave{i}_{\mathrm{i}}+\stackrel{\circ}{\mathrm{at}}_{\mathrm{it}}
$$

where $\mu_{\mathrm{i}}$ is a time-invariant effect unique to individual i, $\lambda_{\mathrm{t}}$ is a time effect common to all individuals in period $\mathrm{t}$, and $\varepsilon_{\mathrm{it}}$ is an individual time-varying error distributed independently across individuals and time and independently of all $\mu_{\mathrm{i}}$ and $\lambda_{\mathrm{t}}$ (cf. Chamberlain, 1984; and Heckman and Robb, 1985). This difference in differences estimator of $\alpha_{0}$, possibly including a set of control regressors that vary both across units and time, is the most widely used estimator in policy evaluation (see, among many others, Angrist and Lavy, 2001; Dufflo, 1998; PROGRESA, 1999; and Rosenzweig and Wolpin, 1986). Although the difference in difference approach is extensively applied in

\footnotetext{
${ }^{14}$ Economists have extensively used experiments that allocate treatments exogenously to assess their effects in the presence of heterogeneity (see, e.g., Angrist, 1995; Meyer, 1995; and Rosenzweig and Wolpin, 2000).
} 
the economic literature, it is the exogenous treatment across units and time induced by a political or natural experiment what provides a reliable instrument to identify $\alpha_{0}{ }^{15}$

Consider the evaluation of the impact of school decentralization on test outcomes. Suppose that test outcomes are available by school. Then, the difference in difference estimator of $\alpha_{0}$ is obtained by estimating the following regression function:

$$
\text { ScorePub }_{\text {jit }}=a_{0} \mathrm{dSC}_{\mathrm{jit}}+\ddot{e}_{\mathrm{t}}+\grave{i}_{\mathrm{i}}+\stackrel{\circ}{\mathrm{jit}}_{1}
$$

where ScorePub $\mathrm{j}_{\mathrm{jit}}$ is the test outcome of public school $\mathrm{j}$ (the average test outcome over students) in province $\mathrm{i}$ and year $\mathrm{t}$, and $\mathrm{dSC}_{\mathrm{jit}}$ is a zero-one indicator that equals unity if school $\mathrm{j}$ in period $\mathrm{t}$ is administered by the national government.

Unfortunately, test outcomes are not available at the school level, but separately aggregated by province and year for public and private schools. Thus, we have that:

$$
\text { ScorePub }{ }_{i t}=a_{0} P_{i t}+\ddot{e}_{t}+\grave{i}_{i}+\stackrel{\circ}{i t}_{1}
$$

where $\mathrm{ScorePub}_{\mathrm{it}}$ is the average test score over all students that attend the last year of public schools in province $\mathrm{i}$ and year $\mathrm{t}$, and $\mathrm{PC}_{\mathrm{it}}$ is the proportion of students enrolled in the last year of public national schools over the total students enrolled in the last year of public schools in province $\mathrm{i}$ and year $\mathrm{t}$. Therefore, at the province level, the effect of interest is that of $\mathrm{PC}_{\mathrm{it}}$ on $\mathrm{ScorePub}$ it.

\footnotetext{
15 Indeed, most of debate around the validity of a difference in difference estimate always revolves around the possible endogeneity of the interventions themselves.
} 
Models (1) and (2) and hence, model (3), assume that the effect of the policy change on the dependent variable operates immediately. However, that may not be the case. Conspicuously, the dependent variable may respond, instead, to the intensity of exposure to treatment which may accumulate over time. For example, in the case of school decentralization, test outcomes most likely respond to the number of years an student has spent in a public school administered by a provincial government (a public provincial school) instead to respond solely to whether the student is in a public provincial school at the time the test is performed (cf., e.g., Meyer, 1993). ${ }^{16}$ That is, we expect that individual test outcomes respond to the intensity of the treatment at which the student has been exposed.

For example, Dufflo (1998) also uses exposure to treatment as the measure of policy change in an experiment with some similarities to the one we analyze in this paper. She estimates the effect of a large construction of primary schools in Indonesia on school attainment. The policy variable in her study is the average number of schools constructed by the Indonesian program per year in region i during the period spent in primary school by a child of a given cohort birth in region i that followed the normal curriculum.

Similarly, we define our policy variable as the proportion of years that a student in the final year of secondary school in region $\mathrm{i}$ and year $\mathrm{t}$ has spent in a public national school. Thus, at the province level, the effect of interest is the impact of the proportion of years that on average the students of the last year of secondary public school in province $i$ and year t have spent in a national school $\left(\mathrm{Cen}_{\mathrm{it}}\right)$ on $\mathrm{ScorePub}_{\mathrm{it}}$. Consequently, the identification strategy in this paper uses the fact that exposure to school decentralization

\footnotetext{
${ }^{16}$ Test outcomes are only available since 1994 while the decentralization of schools took place between 1992 and 1994. Strictly speaking, if $\alpha_{0}$ were of interest, it would not be identified with
} 
of a student in the final year of secondary school varies both by province and student cohort. Letting $\alpha$ be the impact of $\mathrm{Cen}_{\mathrm{it}}$ on $\mathrm{ScorePub}_{\mathrm{it}}$, its difference in difference estimator is given by estimating the following regression function:

$$
\text { ScorePub }_{\text {it }}=\operatorname{aCen}_{i t}+\ddot{e}_{t}+\grave{i}_{i}+\stackrel{\circ}{i t}_{\text {it }}
$$

where, given the specification adopted, a negative (positive) $\alpha$ means that test outcomes increase (decrease) with the level of decentralization.

Naturally, the identification of $\alpha$ may require that we include a set of control variables $\mathbf{x}$ in the regression function (4). Thus, we have that:

$$
\mathrm{ScorePub}_{\mathrm{it}}=\mathrm{áCen}_{\mathrm{it}}+\beta_{0} \mathbf{x}_{\mathrm{it}}+\ddot{\mathrm{e}}_{\mathrm{t}}+\grave{\mathrm{i}}_{\mathrm{i}}+\stackrel{\circ}{\mathrm{it}}_{\mathrm{i}}
$$

It is necessary to highlight the interest of the exercise we realize. Although there is a wide literature that outlines the pros and cons of decentralization, there is no causal evidence of the impact of a national school decentralization program on standardized test outcomes (education quality) while theoretically, the effect may be negative, zero or positive.

Nonetheless, two nuisances may interfere with the experimental design generated by the decentralization policy experiment that we analyze. Firstly, the difference in difference estimator maintains the assumption that the composition of units remains stable before and after the policy change. In our case, this assumption would not hold if

the data available. For that purpose, test outcomes should have been collected since before 1992 . 
the composition of the pool of students of public schools changes in any way that is correlated with the level of centralization (Cen). This may occur if actual or prospective students non-randomly change their election of school between public and private school after decentralization. We evaluate this possible nuisance in our empirical analysis.

Secondly, even if the units treated are not selected in response to values of the error term $\varepsilon$ in model (5), it may be the case that Cen and $\varepsilon$ are correlated and hence, Cen is not exogenous for the parameter of interest, $\alpha$ (cf. Engle et al., 1983). Unobservable factors may affect both public and private test outcomes by province and induce a correlation between Cen and $\varepsilon$. A particularly worrisome case is one in which the evolution of test outcomes by province are different due to unobservable factors violating the common time effects assumption of model (5). It could also be the case that some provinces apply others programs that affect test outcomes while some provinces do not, inducing, specially in a small population like the one treated in our case, a correlation between Cen and $\varepsilon .^{17,18}$

Our empirical strategy to control for likely differences in the evolution of test outcomes across provinces is to contrast public test scores with private test scores by province. Thus, we argue that $\alpha$, the causal effect of school decentralization on test outcomes, is identified by estimating the following two-way fixed effect error component model:

\footnotetext{
${ }^{17}$ For example, the implementation of the Education Federal Law introduced further reforms in the Argentine education system. The degree of implementation of these reforms differs across provinces in a way that could potentially be correlated with the process of decentralization.

${ }^{18}$ Moreover, it could be the case that the evolution of test outcomes in a province is related to unobserved factors that are correlated with the pre-decentralization level of Cen inducing a correlation between this variable and $\varepsilon$ in model (5). Unfortunately, the lack of pre-intervention test outcomes precludes us to test the common time effects assumption of model (5) (cf. Heckman and Hotz, 1989).
} 


$$
\text { Score }_{\text {it }}=\operatorname{áCen}_{\mathrm{it}}+\beta_{1} \mathbf{x}_{\mathrm{it}}+\tau_{\mathrm{t}}+v_{\mathrm{i}}+\omega_{\mathrm{it}}
$$

where the dependent variable is Score $_{i t}=$ ScorePub $_{i t}-$ ScorePriv $_{i t}$, instead of ScorePub it $_{\text {it }}$ and where ScorePrivit is the average test score over all students that attend the last year of private schools in province $\mathrm{i}$ and year t. Then, the statistical model to estimate $\alpha$ is a difference in difference of the difference of public and private test outcomes. $v_{i}$ is a timeinvariant effect unique to province $\mathrm{i}, \tau_{\mathrm{t}}$ is a time effect common to all provinces in period $\mathrm{t}$, and $\omega_{\mathrm{it}}$ is an individual time-varying error distributed independently across individuals and time and independently of all $v_{\mathrm{i}}$ and $\tau_{\mathrm{t}}$ and, crucially, uncorrelated with Cen. Note that $\alpha$ still is the causal effect of school decentralization on public schools test outcomes. This assumes that the decentralization of schools only affects the test outcomes of public schools. ${ }^{19}$ Otherwise, $\alpha$ estimates the differential effect of decentralization on test outcomes between public and private schools.

Thus, model (6) controls for the existence of different trends in the evolution of test outcomes that are specific to each province. Additionally, it controls for any transitory shock in province $\mathrm{i}$ and year $\mathrm{t}$ that affects both private and public test outcomes. Again, these common shocks may severely distort the estimate of $\alpha$ in a small sample like the one we analyze. Under the presence of different trends in the evolution of test outcomes that are province specific, only the difference in difference estimate of the difference of test outcomes identifies the causal effect of school decentralization on test scores.

\footnotetext{
${ }^{19}$ The only relevant mechanism that we foresee that could make public school decentralization affect private school scores during the period studied is through the migration of students. Our
} 
The discussion so far involves a stylized description of the world, wherein causal effects are the same for every unit (province). However, the theory of decentralization highlights several channels through which decentralization may differently affect outcomes. Decentralization effects may depend on the technical capabilities of local governments, the risks of capture by local elites, or the significance of agency costs. Thus, our estimate of $\alpha$ may be subsuming positives as well as negatives impacts of school decentralization on test outcomes. This may not only obscure the existence of heterogeneous impacts on test outcomes but also impede us to learn about the channels through which decentralization operates. To investigate this heterogeneity of program impact, we postulate the following model that encompasses model (6):

$$
\operatorname{Score}_{\mathrm{it}}=\dot{a}_{1} \operatorname{Cen}_{\mathrm{it}}+\phi_{0}\left(\mathrm{z}_{\mathrm{it}} \times \mathrm{Cen}_{\mathrm{it}}\right)+\phi_{1} \mathrm{z}_{\mathrm{it}}+\beta_{2} \mathbf{x}_{\mathrm{it}}+\kappa_{\mathrm{t}}+l_{\mathrm{i}}+\zeta_{\mathrm{it}}
$$

where $z_{i t}$ is a covariate supposed to affect the way decentralization impacts on test outcomes that may or may not vary over time. In the latter case, $\phi_{1}$ is not identified. $l, \kappa$, and $\zeta$ satisfy the same properties that $v, \tau$, and $\omega$. Then, the impact of school decentralization on test outcomes is given by:

$$
\frac{\partial \operatorname{Score}_{\mathrm{it}}}{\partial \operatorname{Cen}_{\mathrm{it}}}=\dot{a}_{1}+\phi_{0} \mathrm{z}_{\mathrm{it}}
$$

empirical results on migration presented in the next section deny empirical support to this possibility. 
If $\phi_{0}=0$, the impact of decentralization on test outcomes is homogenous with respect to $\mathrm{z}$, while if it is statistically different from zero, the impact of decentralization on test outcomes depends on z. Advantageously, we may also identify why decentralization affects differently to different provinces.

Finally, we need to consider the instrumentation of the standardized tests. For 1994 through 1996, a representative sample of fifth-year students was tested in each province, while after 1996, every fifth-year student has to answer the test. Thus, between 1994 and 1996, tests outcomes present sampling variability while, after 1996, they do not. Thus, for example, $\zeta_{\text {it }}$ in equation (7) is not an i.i.d random variable. Rewriting equations (5) to (7) we have:

$$
\mathrm{y}_{\mathrm{it}}=\psi \mathbf{w}_{\mathrm{it}}+\stackrel{\circ}{\mathrm{it}}_{\mathrm{it}}
$$

where $\mathrm{y}_{\mathrm{it}}$ stands alternatively for $\mathrm{Score}_{\mathrm{it}}$ and $\mathrm{ScorePub}_{\mathrm{it}}, \psi$ is the appropriate vector of parameters, $\mathbf{w}_{\mathrm{it}}$ is the vector of regressors (including the province and year fixed effects dummy variables) and where $\varepsilon_{\mathrm{it}} \sim$ i.i.d $\left(0, \sigma_{1}\right)$ for $\forall \mathrm{i}$ and $\mathrm{t}=1994,1995,1996$, and $\varepsilon_{\mathrm{it}} \sim$ i.i.d $\left(0, \sigma_{2}\right)$ for $\forall \mathrm{i}$ and $\mathrm{t}=1997,1998$.

The estimator of $\psi$ that we apply is the Estimated Generalized Least Squares Dummy Variables Estimator $\left(\psi_{\mathrm{GLS}}\right)$. This estimator has the advantage over the Least Squares Dummy Variables Estimator that the estimator of the variance-covariance matrix of $\psi_{\mathrm{GLS}}$ is consistent. As a result, the statistical inference we conduct in the next section is (asymptotically) valid. Thus, to estimate $\psi$ we first estimate $\sigma_{1}$ and $\sigma_{2}$ and then we 
transform the observations of both $\mathrm{y}_{\mathrm{it}}$ and $\mathbf{w}_{\mathrm{it}}$ by dividing them by the estimate of $\sigma_{1}$ for $\mathrm{t}$ $=1994,1995$ and 1996 and by the estimate of $\sigma_{2}$ for $\mathrm{t}=1997$ and 1998 .

\section{Results}

In Table 2 we present the results of the estimation of equation (6) under several specifications. The dependent variable is Score, the difference of the test outcomes between public and private schools. First, in Column 1, we do not include any control variable. We find a negative and statistically significant effect of Cen on Score, that is, we find that school decentralization improves the performance of public school students. ${ }^{20}$ The average effect of decentralization on test outcomes is notable. We predict that, on average, between 1994 and 1998, test outcomes of public schools improved 0.7 standard deviations of its distribution as a result of the decentralization process. ${ }^{21}$

In Column 2 we add a set of control variables: monthly average real teachers' wage (Wage), ${ }^{22}$ the unemployment rate (Unemp), the household real income (Income) and an inequality measure (Ineq) by province and year. The last three variables are obtained from the ongoing permanent household survey that covers, almost only, the population of

\footnotetext{
${ }^{20}$ Remember that $\alpha$ estimates the causal effect of decentralization on public school outcomes, even though, to build what we believe is the correct counterfactual, the dependent variable in the regression function we estimate is Score. As we already mentioned, however, if the decentralization of schools would have also affected private test outcomes, then, $\alpha$ would be an estimate of the differential effect between public and private schools of the decentralization on test outcomes.

${ }^{21}$ This statistics is calculated as $\frac{a ́}{\text { Ó }_{\text {ScorePub }}} \ddot{A}_{98,94} \bar{C}$ en, where $\sigma_{\text {ScorePub }}$ is the standard deviation of ScorePub. It is worth to note that $\sigma_{\text {ScorePub }}>\sigma_{\text {Score }}$.

${ }^{22}$ As secondary school teachers' wages are not regularly available, we use primary school wages that must be strongly correlated.
} 
the capitals of the provinces. Thus, they are less than perfect estimates of the respective parameters at the province level. This is an important additional reason to contrast the result of public and private schools test outcomes when attempting to identify the impact of the decentralization of schools on public test scores.

In terms of the results, it is not clear a priori whether these variables should have any impact on Score and, if they have any, it is not obvious what is their sign. Unemployment shows no effect on Score while both income and inequality have a negative and statistically significant effect. We do not find any effect of Wage on Score. More importantly, we find a negative and statistically significant effect of Cen on Score once we include this set of controls. The estimated average effect of decentralization on test outcomes is higher than the one estimated without including the control variables.

In column 3 we exclude Unemployment from the set of controls and the results remain completely unchanged. Finally, in Column 4 we also exclude Wage from the set of control variables and the results remain unaltered. More importantly, the effect of decentralization on test outcomes is similar across the specifications in Columns 2 through 4. Thus, we find that the performance of the public schools improves significantly with the decentralization of schools. We predict that on average, between 1994 and 1998, test outcomes of public schools improved 1.2 standard deviations of its distribution as a result of the decentralization process. ${ }^{23}$

Our estimates in Table 2 consider that the causal effects of decentralization are the same for every province. However, the theory of decentralization highlights several channels through which decentralization may differently affect test outcomes. In what

\footnotetext{
${ }^{23}$ When we estimate the same models reported in Table 2 for ScorePub instead of Score, we do not find any statistically significant effect of Cen for any of the specifications.
} 
follows, we investigate if decentralization impacts dissimilarly to provinces with different characteristics, that is, we evaluate whether the impact of the decentralization of schools on test outcomes is homogenous or heterogeneous across province characteristics.

Although "bringing decisions closer to the people" may be generally optimal, the advantages of decentralization may dilute when local governments lack technical capabilities. We use provincial fiscal surpluses and deficits to proxy for the quality of province governments. Provincial fiscal disorders in Argentina are frequent and typically associated with misgovernments. Moreover, provincial fiscal results may have an important impact on the education sector. In several occasions, provincial fiscal deficits generate reductions and delays in teachers' wage payments that prompt long strikes. ${ }^{24} \mathrm{We}$ first interact provincial fiscal results (normalized by province gross output) with our policy variable. ${ }^{25}$

In Table 3 we report the interaction of Cen with Fiscal Result, that is, we estimate equation (7) where $\mathrm{z}$ first equals Fiscal Result $\mathrm{t}_{\mathrm{t}}$ and then it equals Fiscal Result $\mathrm{t}_{\mathrm{i}}$, the province average over time. In Column 1 we do not include other control variables than Fiscal Result ${ }_{\mathrm{it}}$ itself. Interestingly, we find that the effect of school decentralization on test outcomes is heterogeneous. It depends on the province fiscal result.

\footnotetext{
${ }^{24}$ For example, in 1995 and 1996 wages were reduced in Misiones, Entre Rios, San Juan, Santa Fe, Rio Negro, Corrientes, and Neuquen; while delays occurred in La Rioja, Entre Rios, Jujuy, Tucuman, Salta, Cordoba, Misiones, Rio Negro, Capital, Neuquen and Buenos Aires. Over 170 class-days in 1995, strikes lasted for 50 days in San Juan, 40 in La Rioja, 30 in Jujuy, 10 in Misiones, 120 in Rio Negro, 20 in Salta and 70 in Cordoba (Senen Gonzalez, 1997). Provincial fiscal crises provoked federal interventions in Santiago del Estero in 1993 and in Corrientes in 1999. In Santiago del Estero, a teachers' strike had lasted for 50 days (La Nación, October 30, 1993), while there were basically no classes in Corrientes during that whole year (Clarín, November 16, 1999). More recently, a long teachers' strike prompted by a fiscal crisis is affecting the province of Buenos Aires (Clarín, September 14, 2001).

${ }^{25}$ Provincial fiscal results in our sample range between $16 \%$ of deficit and $4 \%$ of surplus, averaging a deficit of $2 \%$.
} 
As expected, we find that the higher the provincial fiscal deficit, the smaller the positive impact of decentralization on test outcomes, being possible that this positive impact disappears or, even worse, reverts its sign for provinces with huge fiscal deficits. We also find that Fiscal Result has a positive and significant direct effect on test outcomes.

In Column 2 we add the complete set of control variables (Unemp, Ineq, Income, and Wage). Similarly to what we report in Table 2, the impact of school decentralization on test outcomes increases once we control by these variables. We still find that the higher the provincial fiscal deficit, the smaller the positive impact of decentralization on test outcomes. Again, the fiscal stance shows a positive and significant direct effect on test scores. $^{26}$

Figure 1 illustrates the relationship between Fiscal Result and the effect of school decentralization on test outcomes measured in units of standard deviation of ScorePub,

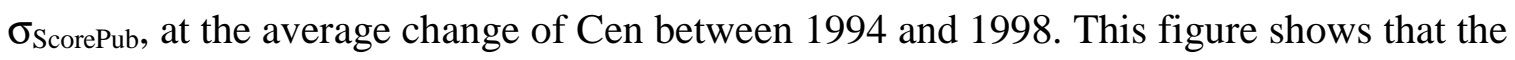
effect of school decentralization on test outcomes is null for a fiscal deficit in terms of gross product of approximately 10 percent. Only a province with a very high fiscal deficit could be negatively affected by the decentralization of schools.

\footnotetext{
${ }^{26}$ When we estimate the same model reported in Column 2 of Table 3 for ScorePub instead of Score, we find similar qualitative results. The effect of school decentralization on test outcomes still depends on the provincial fiscal situation. Now, test outcomes only improve for provinces running surpluses.
} 


\section{Figure 1: Change in test scores in units of standard deviation of ScorePub}

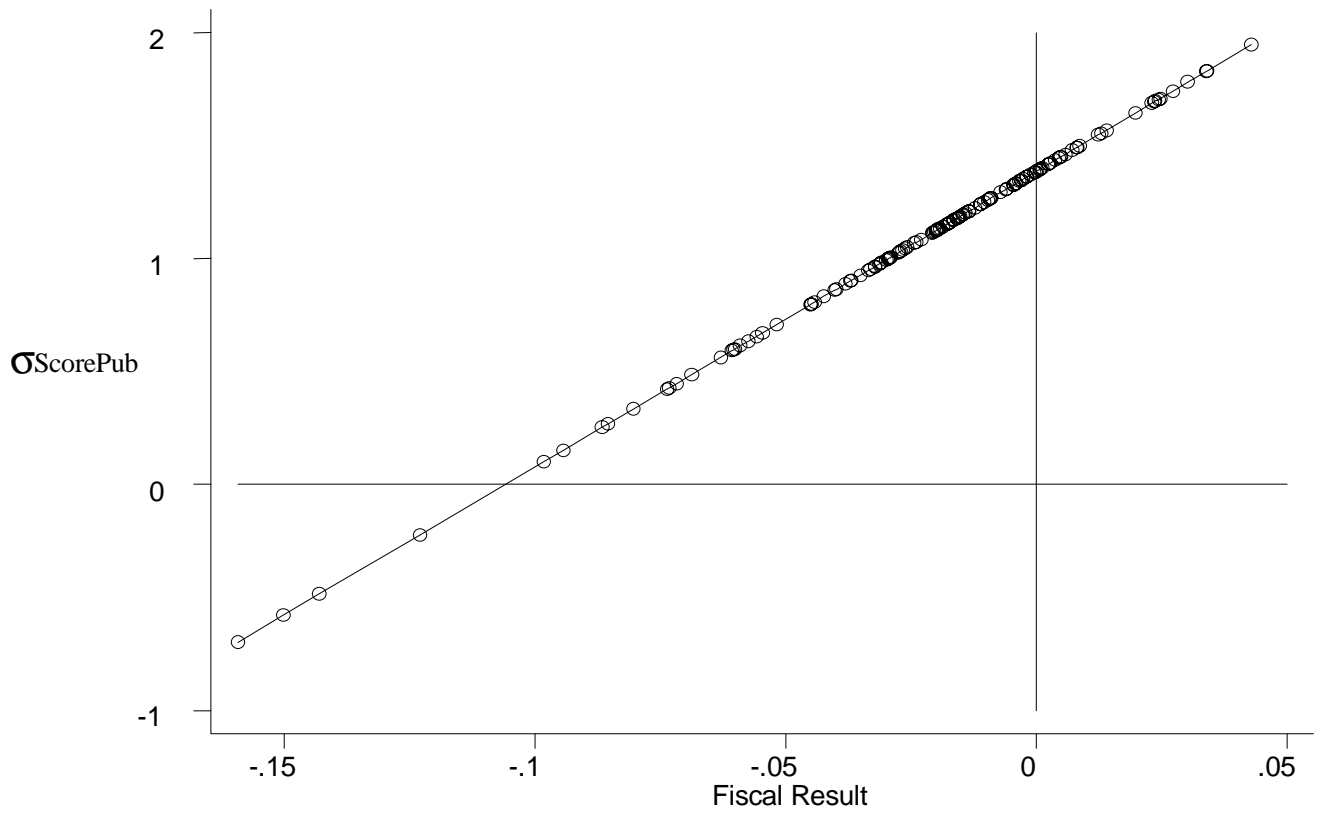

Note: Figure computed by using the parameter estimates in Table 3, Column 2 and the actual observations of Fiscal Result it. $_{\text {. }}$

In Column 3 we report the interaction of Cen with Fiscal Result $\mathrm{i}_{\mathrm{i}}$, the average of Fiscal Result $t_{\text {it }}$ over time. The results are very similar to the one we obtain in Column 2. Thus, none of the conclusions change when we consider the average level of Fiscal Result by province instead of the current level.

In Table 4 we estimate equation (7) exploring other possible channels through which the impact of school decentralization could be heterogeneous. Decentralization may allow for a better match between government outputs and local preferences. It may also reduce agency costs improving accountability of political agents. However, we may argue that the heterogeneity of preferences and the collective decision problems are still 
significant in large provinces, weakening the decentralization benefits. Thus, the effects of decentralization may depend on province size.

In the first three columns of Table 4, we proxy for province size alternatively using surface (Sur), population as of the 1991 Census (Pop), and 1991 population density (Den). We find that the effect of school decentralization on test outcomes is not heterogeneous with respect to these size variables.

Moreover, the benefits of decentralization may dilute if the capture of the political process by interest groups is easier at the local level. We proxy for political capture using Alt, a zero-one indicator that equals unity if the political party governing the province has changed since the return to democracy in 1983. Again, the interaction term reported in Column 4 is not statistically significant. Thus, it seems that the effect of decentralization on test outcomes is homogeneous with respect to all the variables included in Table 4 .

Finally, we need to provide evidence in favor of our empirical strategy. To avoid the rejection of the interpretation of the results of the effect of school decentralization on test outcomes that we reported, we need to show that during the period studied there has not been migration between public and private schools induced by the decentralization. ${ }^{27} \mathrm{We}$ explore whether it is the case that the proportion of students in public secondary schools over total secondary school students (SharePub) is correlated with decentralization. We estimate the following two-way fixed effect error component model:

\footnotetext{
${ }^{27}$ Strictly, we require that the distribution of student abilities between public and private schools does not change during the period studied. However, it is not possible to evaluate this condition. Thus, we evaluate the weaker requirement that the proportion of students in public (private) schools does not change during the period studied. Nevertheless, it is practically unfeasible that the distribution of student abilities changes substantially without observing a significant change in the distribution of students between public and private schools, which is what we test.
} 


$$
\text { SharePub }_{\text {it }}=ð_{0} \operatorname{Cen}_{i t}+ð_{1} \mathbf{x}_{i t}+\ddot{e}_{t}+\grave{i}_{i}+\stackrel{̊}{i t}_{1}
$$

where $\mu_{\mathrm{i}}$ is a time-invariant effect unique to province $\mathrm{i}, \lambda_{\mathrm{t}}$ is a time effect common to all provinces in period $\mathrm{t}$, and $\varepsilon_{\mathrm{it}}$ is an individual time-varying error. ${ }^{28}$

Table 5 reports the result of estimating equation (10) for the period 1994 to 1998 , that is, the same period for which we estimate the models reported in Tables 2 to 4 . We do not find any relation between SharePub and Cen. Indeed, in both regressions the coefficient $\pi_{0}$ is numerically equal to cero and statistically insignificant. Thus, our empirical analysis shows no relation between the proportion of students in public secondary schools over total secondary school students and the level of decentralization for the period studied. Accordingly, we do not find any evidence indicating that students that would have attended public schools without decentralization and whose abilities are below the average abilities of private school students, have moved to the private schools as a result of decentralization, spuriously inducing the effect of school decentralization on test outcomes that we report in this section.

\section{Conclusions}

Although there is a wide literature that outlines the pros and cons of decentralization, there is no evidence on the causal effect of school decentralization on education quality.

\footnotetext{
${ }^{28}$ Alternatively, we could have estimated a model using a zero-one indicator variable that equals unity if the decentralization of schools was operative for province i in period t. However, given the potentially high switching costs of school change for existing students, we may not observe an immediate effect of school decentralization on migration. Migration should mainly affect incoming first-year students. Thus, if the migration of students between public and private schools takes some time after decentralization, the model we estimate is more appropriate.
} 
The contribution of this paper is to evaluate the impact of the Argentine secondary school decentralization program of the early 1990's on students' standardized test scores.

The Argentine decentralization program generated an exogenous variation in the jurisdiction of administration of secondary schools across time and space that provides an instrument to identify our parameter of interest. Our identification strategy uses the fact that exposure to school decentralization varied both by province and student cohort. We also exploit the fact that, by contrasting public and private school test outcomes, we are able to control for the effect of unobservable factors that may differentially affect the evolution of student performance across provinces. Thus, our estimator of the causal effect of school decentralization on test outcomes is the conditional difference in difference of the difference of public and private test outcomes. Although we provide arguments and evidence in favor of this identification strategy, its validity could be disputed.

We focus on the effects of school decentralization on education quality, while we recognize that standardized test scores do not capture all the dimensions of school system achievements. Additionally, our argument that test outcomes respond to the amount of time a secondary school final-year student has spent under a certain type of administration, instead of responding solely to the type of school the student attends at the time the test is performed, could be criticized.

Having these caveats in mind, our results suggest that decentralization improved the performance of students in test scores. We find that the performance of public schools improves significantly with decentralization. We predict that, on average, public school 
test outcomes improved 1.2 standard deviations of its distribution between 1994 and 1998 as a result of the decentralization process.

Although decentralization may be generally optimal, its advantages may dilute when schools are transferred to severely mismanaged provinces. Indeed, we find that the effect of school decentralization on test outcomes is heterogeneous depending on provincial fiscal performance. The higher the provincial fiscal deficit, the smaller the positive impact of decentralization. Moreover, the effect of school decentralization on test outcomes may become negative for provinces running significant fiscal deficits. Thus, we conclude that, although school decentralization generally shows a positive impact on education equality, advice should be cautious when there are doubts on the competence of local governments. 


\section{Appendix: Description of the Data}

Summary Statistics

\begin{tabular}{c|ccccc}
\hline \hline Variable & Observations & Mean & Std. Dev. & Min & Max \\
\hline Score & 118 & -9.16629 & 4.56703 & -25.18 & 2.380001 \\
Cen & 120 & 15.92418 & 15.64173 & 0 & 60.968 \\
Unemp & 115 & 0.115676 & 0.038741 & 0.040785 & 0.202752 \\
Income & 115 & 302.0589 & 86.63253 & 188.3864 & 579.403 \\
Ineq & 115 & 8.674907 & 1.171806 & 6.250445 & 12.11429 \\
Wage & 114 & 552.026 & 150.4942 & 320.8194 & 969.48 \\
Fiscal Result & 120 & -0.02045 & 0.033302 & -0.15928 & 0.04288 \\
SharePub & 120 & 80.7765 & 10.6301 & 52.2339 & 93.1644 \\
Sur & 24 & 156719.8 & 194090.1 & 200 & 1002445 \\
Pop & 24 & 1448686 & 2683194 & 89992 & 13379401 \\
Den & 24 & 641.8789 & 3087.995 & 0.089773 & 15139.43 \\
Alt & 24 & 0.583333 & 0.50361 & 0 & 1 \\
\hline
\end{tabular}

\section{Data Definitions and Sources}

\begin{tabular}{|c|c|c|}
\hline Variable & $\begin{array}{ll}\text { Definition } \\
\end{array}$ & Source \\
\hline ScorePub $_{i t}$ & $\begin{array}{l}5^{\text {th }} \text { year test scores (measured as the number of } \\
\text { right answers as a percentage of total answers) for } \\
\text { public non-technical schools in province } i \text { in period } \\
t \text {. Not available for Santa Cruz for } 1995 \text {. }\end{array}$ & $\begin{array}{l}\text { Ministerio de Cultura y Educación } \\
\text { (MCyE), Operativos Nacionales de } \\
\text { Evaluación, and Llach et al (1999) }\end{array}$ \\
\hline ScorePriv $_{i t}$ & $\begin{array}{l}5^{\text {th }} \text { year test scores (measured as the number of } \\
\text { right answers as a percentage of total answers) for } \\
\text { private non-technical schools in province } i \text { in } \\
\text { period } t \text {. Not available for Santa Cruz for } 1994 \text { and } \\
1995 \text {. }\end{array}$ & See ScorePub \\
\hline Score $_{i t}$ & $=$ ScorePub $_{i t}$-ScorePriv ${ }_{i t}$ & See ScorePub \\
\hline ShareNac $_{i t}$ & $\begin{array}{l}\text { Students attending national secondary schools as } \\
\text { percentage of students attending public secondary } \\
\text { schools in province } i \text { in period } t \text {. }\end{array}$ & $\begin{array}{l}\text { MCyE: Centro Nacional de } \\
\text { Estadísticas de la Educación, } \\
\text { Dirección General Red Federal de } \\
\text { Información, and Instituto para el } \\
\text { Desarrollo de la Calidad Educativa } \\
\text { (IDECE) }\end{array}$ \\
\hline $\mathrm{Cen}_{i t}$ & $\begin{array}{l}=\sum_{j=0}^{4} \frac{\text { ShareNac }_{i(t-j)}}{5} . \text { Proportion of years that on } \\
\text { average the students of } 5^{\text {th }} \text { of public secondary } \\
\text { schools in province } i \text { and year } t \text { have spent in } \\
\text { public national schools. }\end{array}$ & See ShareNac \\
\hline Unemp $_{i t}$ & $\begin{array}{l}\text { Unemployment rate (May and October average) in } \\
\text { period } t \text { of the surveyed cities located in province } i \\
\text { (population weighted average if data is available }\end{array}$ & $\begin{array}{l}\text { Permanent Household Survey (EPH), } \\
\text { INDEC }\end{array}$ \\
\hline
\end{tabular}




\begin{tabular}{|c|c|c|}
\hline & $\begin{array}{l}\text { for more than one city in province } i \text { ). None of Rio } \\
\text { Negro cities are surveyed. }\end{array}$ & \\
\hline$\overline{\text { Income }_{i t}}$ & $\begin{array}{l}\text { Household income (May and October average in } \\
\text { constant } 1995 \text { pesos) in period } t \text { for households } \\
\text { with positive income in the surveyed cities located } \\
\text { in province } i \text { (population weighted average if data } \\
\text { is available for more than one city in province } i \text { ). } \\
\text { None of Rio Negro cities are surveyed. }\end{array}$ & See Unemp \\
\hline Ineq $_{i t}$ & $\begin{array}{l}\text { Ratio of top } 10 \% \text { to bottom } 10 \% \text { household income } \\
\text { (May and October average) in period } t \text { for } \\
\text { households with positive income in the surveyed } \\
\text { cities located in province } i \text { (population weighted } \\
\text { average if data is available for more than one city } \\
\text { in province } i \text { ). None of Rio Negro cities are } \\
\text { surveyed. }\end{array}$ & See Unemp \\
\hline Wage $_{i t}$ & $\begin{array}{l}\text { Monthly gross wage in } 1995 \text { constant pesos for } \\
\text { public school primary teachers in province } i \text { in } \\
\text { period } t \text {. Six observations are not available. }\end{array}$ & $\begin{array}{l}\text { MCyE, Series Salariales 1989-1997, } \\
\text { Análisis de Composición (November } \\
\text { 1998), and Informe Indicativo de } \\
\text { Salarios Docentes (March 2000) }\end{array}$ \\
\hline$\overline{G D P_{i t}}$ & $\begin{array}{l}\text { Gross geographic product for province } i \text { in period } t \\
\text { at current prices }\end{array}$ & $\begin{array}{l}\text { Consejo Federal de Inversiones and } \\
\text { INDEC }\end{array}$ \\
\hline$\overline{\text { Fiscal Level }}{ }_{i t}$ & $\begin{array}{l}\text { Fiscal result (deficit or surplus) of government of } \\
\text { province } i \text { in period } t \text {. }\end{array}$ & DataFiel \\
\hline Fiscal Result $_{i t}$ & $\begin{array}{l}=\text { Fiscal } \text { Level }_{i t} / G D P_{i t} \text {. Fiscal result as percentage } \\
\text { of gross geographic product of government of } \\
\text { province } i \text { in period } t \text {. }\end{array}$ & See Fiscal Level and GDP \\
\hline SharePub ${ }_{i t}$ & $\begin{array}{l}\text { Students attending public secondary schools as a } \\
\text { percentage (multiplied by 100) of students } \\
\text { attending total secondary schools in province } i \text { in } \\
\text { period } t \text {. }\end{array}$ & See ShareNac \\
\hline Sur & Area $\left(\right.$ in $\mathrm{km}^{2}$ ) of province $i$ & INDEC \\
\hline$P o p_{i}$ & Population of province $i$ in 1991. & 1991 Census INDEC \\
\hline $\mathrm{Den}_{i}$ & $=$ Population $_{i} /$ Surface $_{i}$ & See Population and Surface \\
\hline$A l t_{i}$ & $\begin{array}{l}\text { Dummy variable that equals } 1 \text { if the political party } \\
\text { governing the province changed between } 1983 \text { and } \\
2000 \text {, and } 0 \text { otherwise. }\end{array}$ & $\begin{array}{l}\text { Jones, Mark P., Pablo Sanguinetti and } \\
\text { Mariano Tommasi, 2000, "Voters as } \\
\text { Fiscal Liberals", mimeo, Centro de } \\
\text { Estudios para el Desarrollo } \\
\text { Institucional (CEDI). }\end{array}$ \\
\hline
\end{tabular}




\section{References}

Angrist, J., 1995, "Introduction to the JBES Symposium on Program and Policy Evaluation", Journal of Business and Economic Statistics 13, pp. 249-88.

Angrist, J. and V. Lavy, 2001, "Does Teacher Training Affect Pupil Learning? Evidence from Matched Comparisons in Jerusalem Public Schools", Journal of Labor Economics 19, pp. 343-69.

Chamberlain, G., 1984, "Panel Data", in Griliches, Z. and M. Intriligator (eds.), Handbook of Econometrics, North-Holland.

Bardhan, Pranab and Dilip Mookherjee, 1998, "Expenditure Decentralization and the Delivery of Public Services in Developing Countries”, CIDER Working Paper C98/104.

Becker, G., 1964, Human Capital: A Theoretical and Empirical Analysis, with Special Reference to Education, Columbia University Press.

Besley, Timothy J. and Stephen Coate, 2000, "Centralized versus Decentralized Provision of Local Public Goods: A Political Economy Analysis", NBER Working Paper No. W7084.

Bird, Richard M. and Vaillancourt, Francois (eds.), 1998, Fiscal Decentralization in Developing Countries, Cambridge, New York and Melbourne: Cambridge University Press.

Burki, Shahid Javed; Guillermo E. Perry, and William R. Dillinger, William R., 1999, Beyond the Center: Decentralizing the State, Washington, D.C., World Bank.

Dufflo, E., 1998, "Schooling and Labor Market Consequences of School Construction in Indonesia: Evidence from an Unusual Policy Experiment", forthcoming American Economic Review.

Dussel, Inés, 1995, "La Situación del Sistema Educativo Argentino", mimeo, FLACSO.

Engle, R., D. Hendry and J-F. Richard, 1983, "Exogeneity", Econometrica 51, pp. 277-304.

Eskeland, Gunnar S. and Deon Filmer, 2000, "Does Decentralization Improve Learning? Autonomy and Parental Participation in Argentine Schools", mimeo, World Bank.

Faguet, Jean Paul G., 2001, "Does Decentralization Increase Government Responsiveness to Local Needs? Evidence from Bolivia", World Bank Policy Research Working Paper No. 2516.

Fukasaku, Kiichiro and Ricardo Hausmann, 1998, Democracia, Descentralización y Déficit Presupuestarios en América Latina, Inter-American Development Bank and OECD.

Grindle, Merilee, 2000, “Designing Reforms: Problems, Solutions, and Politics”, KSG Working Paper No. 01-020.

Habibi, Nadir, Cindy Huang, Diego Miranda, Victoria Murillo, Gustav Ranis, Mainak Sarkar, and Frances Stewart, 2001, "Decentralization in Argentina", Yale Economic Growth Center Discussion Paper No. 825.

Heckman, J. and V. Hotz, 1989, "Choosing Among Alternative Nonexperimental Methods for Estimating the Impact of Social Programs: The Case of Manpower Training", Journal of the American Statistical Association 84, pp. 862-74.

Heckman J. and P. Klenow, 1997, Human Capital Policy, University of Chicago Press, Chicago.

Heckman, J. and R. Robb, 1985, "Alternative Methods for Evaluating the Impact of Interventions: An Overview", Journal of Econometrics 30, pp. 239-67.

Hoxby, Caroline M., 2000, "Does Competition among Public Schools Benefit Students and Taxpayers?" American Economic Review, 90(5): 1209-38.

Jimenez, E and Y. Sawada, 1999, "Do Community-Managed Schools Work? An Evaluation of El Salvador's EDUCO Program.” World Bank Economic Review 13(3): 415-41.

King, Elizabeth M. and Berk Ozler, 2000, "What's Decentralization Got To Do With Learning? Endogenous School Quality and Student Performance in Nicaragua" Development Research Group, World Bank, Washington, D.C.

Llach, Juan José, Silvia Montoya and Flavia Roldán, 1999, Educación para Todos, IERAL, Córdoba. 
Lockwood, Ben, 1998, “Distributive Politics and the Cost of Decentralization”, CEPR Working Paper No. 2046.

Lopez Murphy, Ricardo, ed., 1995, Fiscal decentralization in Latin America, Inter-American Development Bank, Washington, D.C.

Lucas, Robert E., 1988, "On the Mechanics of Economic Development", Journal of Monetary Economics, 22: 3-42.

Meyer R., 1993, "Can Schools Be Held Accountable for Good Performance? A Critique of Common Educational Performance Indicators", in Hoffman E. (ed.), Essays on the Economics of Education, Kalamazoo, Michigan, W. E. Upjohn Institute for Employment Research.

Meyer, B., 1995, "Natural and Quasi-Experiments in Economics", Journal of Business and Economics Statistics 13, pp. 151-61.

Ministerio de Educacion, 2001, "Estado de Implementacion de la Ley Federal de Educacion al Año 2001."

Oates, Wallace, 1972, Fiscal Federalism, Harcourt Brace, New York.

OECD, 1998, Education at a Glance, in www.oecd.org.

Paes de Barros, Ricardo and Rosane Mendonca, 1998, "The Impact of Three Institutional Innovations in Brazilian Education.”, in Organization Matters: Agency Problems in Health and Education in Latin America, William Savedoff (ed.), Inter-American Development Bank, Washington, D.C.

Porto, Alberto and Leonardo Gasparini, 1998, Descentralización Fiscal: El Caso de las Municipalidades de la Provincia de Buenos Aires, Universidad Nacional de La Plata, La Plata.

PROGRESA, 1999, Evaluación de Resultados del Programa de Educación, Salud y Alimentación: Primeros Avances, Secretaria de Desarrollo Social, Gobierno Federal de México.

Rose-Ackerman, Susan, 1999, Corruption and Government. Causes, Consequences, and Reform, Cambridge University Press, Cambridge.

Rosenzweig, M. and K. Wolpin, 1986, "Evaluating the Effects of Optimally Distributed Programs: Child Health and Family Planning Interventions", American Economic Review 76, pp. 470-82.

Rosenzweig, M. and K. Wolpin, 2000, "Natural "Natural Experiments" in Economics", Journal of Economic Literature 38, pp. 827-74.

Rhoten, Diana R., 1999, "Global-Local Conditions of Possibility: The Case of Education Decentralization in Argentina", Unpublished dissertation, Stanford University.

Senen González, Silvia N. de, 1997, "Ajuste y Reforma Educativa: Dos Lógicas en Pugna”, mimeo, III Congreso Latinoamericano de Administración de la Educación, San Pablo

Savedoff, William (ed.), 1998, Organization Matters: Agency Problems in Health and Education in Latin America, Inter-American Development Bank, Washington, D.C.

Tendler, Judith, 1997, Good government in the tropics, Baltimore and London: Johns Hopkins University Press.

Tiebout, Charles, 1956, "A Pure Theory of Local Expenditures", Journal of Political Economy, 64(5): 416-424.

Tomassi, Mariano, Sebastian Saiegh, and Pablo Sanguinetti, 2000, "Fiscal Federalism in Argentina: Policies, Politics, and Institutional Reform”, Economia, 1(2): 157-211.

Tommasi, Mariano and Federico Weinschelbaum, 1999, "A Principal-Agent Building Block for the Study of Decentralization and Integration", mimeo, Universidad de San Andres.

Willis, Elisa, C. Garman, and S. Haggard, 1999, "The Politics of Decentralization in Latin America", Latin America Research Review, 34(1). 
Table 1

The Variability in Decentralization across Provinces

\begin{tabular}{|l|c|c|c|}
\hline \multirow{2}{*}{ Province } & \multirow{2}{*}{$\begin{array}{c}\text { Transfer } \\
\text { date }\end{array}$} & $\begin{array}{c}\text { Students attending national secondary } \\
\text { schools as a percentage of students } \\
\text { attending secondary public schools }\end{array}$ \\
\cline { 3 - 4 } & & Before & After \\
\hline Buenos Aires & 1-Jan-94 & 58,10 & 0,38 \\
Capital Federal & 1-Jul-92 & 98,36 & 4,61 \\
Catamarca & 1-Jan-93 & 74,24 & 6,03 \\
Chaco & 1-Jan-93 & 33,06 & 0,00 \\
Chubut & 1-Jan-93 & 59,37 & 1,56 \\
Córdoba & 1-Jan-93 & 57,05 & 2,06 \\
Corrientes & 1-Jan-93 & 54,81 & 0,45 \\
Entre Ríos & 1-Jan-93 & 77,79 & 0,00 \\
Formosa & 1-Jan-93 & 37,38 & 0,00 \\
Jujuy & 1-Jan-93 & 61,78 & 0,00 \\
La Pampa & 1-Jan-93 & 75,58 & 1,52 \\
La Rioja & 1-May-92 & 81,42 & 2,43 \\
Mendoza & 1-Aug-92 & 70,39 & 5,14 \\
Misiones & 21-Aug-92 & 39,33 & 0,73 \\
Neuquen & 1-Aug-92 & 31,57 & 0,00 \\
Río Negro & 1-Dec-92 & 8,28 & 0,00 \\
Salta & 1-Mar-93 & 46,49 & 0,73 \\
San Juan & 15-Feb-92 & 89,68 & 6,19 \\
San Luis & 1-Apr-92 & 70,43 & 2,74 \\
Santa Cruz & 1-May-93 & 19,99 & 0,00 \\
Santa Fe & 1-Feb-93 & 52,01 & 2,71 \\
Santiago del Estero & 1-Jan-93 & 59,81 & 0,00 \\
Tierra del Fuego & 1-Jan-93 & 100,00 & 0,00 \\
Tucumán & 1-Dec-92 & 83,45 & 4,38 \\
\hline
\end{tabular}

Source: Ministerio de Educacion. 
Table 2

Test outcomes: Homogeneous impact

\begin{tabular}{|c|c|c|c|c|}
\hline $\begin{array}{c}\text { Dependent } \\
\text { Variable: } \\
\text { Score }\end{array}$ & (1) & (2) & (3) & (5) \\
\hline Cen $_{\text {it }}$ & $\begin{array}{c}-0.14 * \\
(0.08)\end{array}$ & $\begin{array}{c}-0.25^{* * *} * \\
(0.09)\end{array}$ & $\begin{array}{c}-0.25 * * * \\
(0.09)\end{array}$ & $\begin{array}{c}-0.26 * * * \\
(0.09)\end{array}$ \\
\hline Unemp $_{\text {it }}$ & $\ldots \ldots$ & $\begin{array}{c}2.83 \\
(17.00)\end{array}$ & ..... & $\ldots \ldots$ \\
\hline Ineq $_{\text {it }}$ & ..... & $\begin{array}{c}-1.64 * * * \\
(0.43)\end{array}$ & $\begin{array}{c}-1.62 * * * \\
(0.39)\end{array}$ & $\begin{array}{c}-1.79 * * * \\
(0.37)\end{array}$ \\
\hline Income $_{\text {it }}$ & $\ldots \ldots$ & $\begin{array}{c}-0.024 * * \\
(0.009)\end{array}$ & $\begin{array}{c}-0.023 * * \\
(0.009)\end{array}$ & $\begin{array}{c}-0.018 * * \\
(0.008)\end{array}$ \\
\hline Wage $_{\text {it }}$ & $\ldots \ldots$ & $\begin{array}{c}0.007 \\
(0.006)\end{array}$ & $\begin{array}{c}0.006 \\
(0.005)\end{array}$ & $\ldots \ldots$ \\
\hline $\begin{array}{l}\text { Number of } \\
\text { observations }\end{array}$ & 118 & 108 & 108 & 108 \\
\hline $\begin{array}{c}\text { Number of } \\
\text { provinces }\end{array}$ & 24 & 23 & 23 & 23 \\
\hline
\end{tabular}

Notes:

(i) All parameters are estimated by the method of GLS Dummy Variable.

(ii) All regressions include year and province fixed effects.

(iii) *** Statistically different from zero at the 0.01 level of significance. ** Statistically different from zero at the 0.05 level of significance. * Statistically different from zero at the 0.1 level of significance.

(iv) In Column (1), we lose two observations because test scores are not available for 1994 and 1995 for Santa Cruz. In the rest of the table, we lose ten observations because the control variables are not available. 
Table 3

Test outcomes: Heterogeneous impacts

\begin{tabular}{|c|c|c|c|}
\hline $\begin{array}{l}\text { Dependent } \\
\text { Variable: } \\
\text { Score }\end{array}$ & (1) & $(2)$ & (3) \\
\hline $\mathrm{Cen}_{\mathrm{it}}$ & $\begin{array}{c}-0.14 * \\
(0.08)\end{array}$ & $\begin{array}{c}-0.27 * * * \\
(0.09)\end{array}$ & $\begin{array}{c}-0.30 * * * \\
(0.09)\end{array}$ \\
\hline $\begin{array}{c}\text { Cen }_{i t} * \text { Fiscal } \\
\text { Result }_{i t}\end{array}$ & $\begin{array}{c}-1.45^{*} \\
(0.88)\end{array}$ & $\begin{array}{c}-2.55 * * * \\
(0.99)\end{array}$ & $\ldots \ldots$ \\
\hline $\begin{array}{c}\mathrm{Cen}_{\mathrm{it}} * \text { Fiscal } \\
\text { Result }_{\mathrm{i}}\end{array}$ & $\ldots \ldots$ & $\ldots \ldots$ & $\begin{array}{c}-4.92 * * * \\
(1.73)\end{array}$ \\
\hline Unemp $_{\text {it }}$ & $\ldots$. & $\begin{array}{c}2.27 \\
(16.24)\end{array}$ & $\begin{array}{c}11.18 \\
(15.45)\end{array}$ \\
\hline Ineq $_{\text {it }}$ & $\ldots \ldots$ & $\begin{array}{c}-1.25 * * * \\
(0.418)\end{array}$ & $\begin{array}{c}-1.44 * * * \\
(0.398)\end{array}$ \\
\hline Income $_{i t}$ & $\ldots \ldots$ & $\begin{array}{c}-0.025 * * * \\
(0.009)\end{array}$ & $\begin{array}{c}-0.023 * * * \\
(0.008)\end{array}$ \\
\hline Wage $_{i t}$ & $\ldots \ldots$ & $\begin{array}{c}0.006 \\
(0.005)\end{array}$ & $\begin{array}{c}0.006 \\
(0.005)\end{array}$ \\
\hline $\begin{array}{l}\text { Fiscal } \\
\text { Result }_{\text {it }}\end{array}$ & $\begin{array}{c}60.03 * * * \\
(17.17)\end{array}$ & $\begin{array}{c}50.50 * * * \\
(15.81)\end{array}$ & $\ldots \ldots$ \\
\hline F Statistic & $\mathrm{F}(1,87)=1.84$ & $\mathrm{~F}(1,74)=6.0 * *$ & $\mathrm{~F}(1,75)=4.6^{* *}$ \\
\hline $\begin{array}{l}\text { Number of } \\
\text { observations } \\
\text { Number of } \\
\text { provinces }\end{array}$ & $\begin{array}{l}118 \\
24\end{array}$ & $\begin{array}{l}108 \\
23\end{array}$ & $\begin{array}{l}108 \\
23\end{array}$ \\
\hline
\end{tabular}

Notes:

(i) All parameters are estimated by the method of GLS Dummy Variable.

(ii) All regressions include year and province fixed effects.

(iii) *** Statistically different from zero at the 0.01 level of significance. ** Statistically different from zero at the 0.05 level of significance. * Statistically different from zero at the 0.1 level of significance.

(v) In Column (1), we lose two observations because test scores are not available for 1994 and 1995 for Santa Cruz. In the rest of the table, we lose ten observations because the control variables are not available.

(vi) The F statistics test the null hypothesis that equation (8) evaluated at the average level of $\mathrm{z}$ is zero. 
Table 4

Test outcomes: Heterogeneous impacts

\begin{tabular}{|c|c|c|c|c|}
\hline $\begin{array}{l}\text { Dependent } \\
\text { Variable: } \\
\text { Score }\end{array}$ & (1) & (2) & (3) & (4) \\
\hline $\mathrm{Cen}_{\text {it }}$ & $\begin{array}{c}-0.25^{* *} \\
(0.11)\end{array}$ & $\begin{array}{c}-0.24 * * \\
(0.10)\end{array}$ & $\begin{array}{c}-0.24 * * \\
(0.10)\end{array}$ & $\begin{array}{c}-0.18^{*} \\
(0.12)\end{array}$ \\
\hline $\operatorname{Cen}_{\mathrm{it}} * \operatorname{Sur}_{\mathrm{i}}$ & $\begin{array}{c}-0.008 \\
(0.10)\end{array}$ & $\ldots \ldots$ & $\ldots \ldots$ & $\ldots \ldots$ \\
\hline $\mathrm{Cen}_{\mathrm{it}}{ }^{*} \mathrm{Pop}_{\mathrm{i}}$ & $\ldots \ldots$ & $\begin{array}{c}-0.011 \\
(0.01)\end{array}$ & $\ldots \ldots$ & $\ldots \ldots$ \\
\hline $\operatorname{Cen}_{i t} * \operatorname{Den}_{i}$ & ..... & $\ldots \ldots$ & $\begin{array}{l}-0.003 \\
(0.007)\end{array}$ & $\ldots$. \\
\hline $\mathrm{Cen}_{\mathrm{it}} * \mathrm{Alt}_{\mathrm{i}}$ & $\ldots \ldots$ & $\ldots \ldots$ & $\ldots \ldots$ & $\begin{array}{l}-0.078 \\
(0.007)\end{array}$ \\
\hline F Statistic & $\begin{array}{c}\mathrm{F}(1,75)= \\
6.29 * * *\end{array}$ & $\begin{array}{c}\mathrm{F}(1,75)= \\
7.13^{* * *}\end{array}$ & $\begin{array}{c}\mathrm{F}(1,75)= \\
6.09 * *\end{array}$ & $\begin{array}{c}\mathrm{F}(1,75)= \\
5.26^{* *}\end{array}$ \\
\hline $\begin{array}{l}\text { Number of } \\
\text { observations }\end{array}$ & 108 & 108 & 108 & 108 \\
\hline $\begin{array}{c}\text { Number of } \\
\text { provinces }\end{array}$ & 23 & 23 & 23 & 23 \\
\hline
\end{tabular}

Notes:

(i) All parameters are estimated by the method of GLS Dummy Variable.

(ii) All regressions include year and province fixed effects.

(iii) All regressions include Unemp, Income, Ineq and Wage as controls.

(iv) $* * *$ Statistically different from zero at the 0.01 level of significance. ** Statistically different from zero at the 0.05 level of significance. * Statistically different from zero at the 0.1 level of significance.

(vii) We lose two observations because test scores are not available for 1994 and 1995 for Santa Cruz, and ten observations because the control variables are not available.

(viii) The F statistics test the null hypothesis that equation (8) evaluated at the average level of $\mathrm{z}$ is zero.

(ix) $\quad \operatorname{Sur}_{\mathrm{i}}=$ Surface of Province i divided by $1,000,000$.

(x) $\quad$ Pop $_{\mathrm{i}}=$ Population of Province i divided by 1,000,000.

(xi) $\quad \operatorname{Den}_{\mathrm{i}}=$ Density of Province i divided by 1,000 . 
Table 5

Proportion of secondary students in public schools over total secondary students

\begin{tabular}{|c|c|c|}
\hline $\begin{array}{l}\text { Dependent } \\
\text { Variable: } \\
\text { SharePub }\end{array}$ & (1) & (2) \\
\hline $\mathrm{Cen}_{\mathrm{it}}$ & $\begin{array}{c}-0.0009 \\
(0.017)\end{array}$ & $\begin{array}{c}-0.01 \\
(0.021)\end{array}$ \\
\hline Unemp $_{\text {it }}$ & $\ldots \ldots$ & $\begin{array}{c}0.60 \\
(8.16)\end{array}$ \\
\hline Ineq $_{\text {it }}$ & $\ldots \ldots$ & $\begin{array}{l}-0.16 \\
(0.26)\end{array}$ \\
\hline Income $_{\text {it }}$ & $\ldots \ldots$ & $\begin{array}{r}-0.003 \\
(0.008)\end{array}$ \\
\hline Wage $_{\text {it }}$ & $\ldots \ldots$ & $\begin{array}{c}0.001 \\
(0.004)\end{array}$ \\
\hline $\begin{array}{c}\text { Number of } \\
\text { observations } \\
\text { Number of } \\
\text { provinces }\end{array}$ & $\begin{array}{l}120 \\
24\end{array}$ & $\begin{array}{l}110 \\
23\end{array}$ \\
\hline
\end{tabular}

Notes:

(i) All regressions include year and province fixed effects.

(ii) $* * *$ Statistically different from zero at the 0.01 level of significance. ** Statistically different from zero at the 0.05 level of significance. * Statistically different from zero at the 0.1 level of significance.

(iii) In Column (2), we lose ten observations because the control variables are not available. 